\title{
Functional Connectivity and Classification of Actual and Imaginary Motor Movement
}

\author{
Nilima Salankar, Anjali Mishra, Pratikshya Mishra
}

\begin{abstract}
Imaginary Motor movement is an utmost important for the designing of brain computer interface to assist the individual with physically disability. Brain signals associated with actual motor movement include the signal for muscle activity whereas in case of imaginary motor movement actual muscle movement is not present .Authors have investigated the similarity/dissimilarity between the eeg signals generated in both the cases along with the baseline activity. To instruct the brain computer interface signals generated by electrodes of EEG must resemble with actual motor movement. Selection of electrodes placement plays an important role for this purpose. In this study major four regions of the brain has been covered frontal, temporal, parietal and occipital region of the scalp and features are extracted from the signals are standard deviations, kurtosis, skew and mean. Support Vector Machine is used for the classification between actual and imaginary motor movement along with differentiation between baseline and imaginary motor movement and actual motor movement at 14 different electrodes positions. Statistical performances of the classifier have been evaluated by computing sensitivity, specificity and accuracy. The location involved to achieve maximum accuracy for the classification of motor movements (actual and imaginary) and no motor movement is at frontal, temporal and parietal region whereas very less involvement has been seen of occipital region.

INDEX TERMS-EEG, ACTUAL, IMAGINARY
\end{abstract}

\section{INTRODUCTION}

Major difference in case of actual and imaginary motor movement is activation/no activation of muscular signals inside the brain. Actual motor movement comes along with the muscular trigger whereas it is completely missing in case of imaginary motor movement. For the individual with physical disability of hands can't make actual movement but can be operated by giving the signals through the brain. And for the design of brain computer interface(BCI) application for the physically disable individual the correlation between actual and imaginary motor movement should be clearly studied. So definitely network generated among the brain region should be apparently different in case of actual and imaginary motor movement. On the basis of network generated and supporting relevant features movement and no movement can be easily understood by the application through the brain signals which captured by placing

Revised Manuscript Received on December 30, 2019.

* Correspondence Author

Dr. Nilima Salankar, Assistant Professor, Department of School of Computer Science, University of Petroleum and Energy Studies Dehradun, India. (e-mail: nilima11123@gmail.com)

Anjali Mishra, Mtech Student in Computer Science, University of Petroleum and Energy Studies Dehradun, India.

Pratikshya Mishra, Mtech student in Computer Science, University of Petroleum and Energy Studies Dehradun, India.

(C) The Authors. Published by Blue Eyes Intelligence Engineering and Sciences Publication (BEIESP). This is an open access article under the CC BY-NC-ND license (http://creativecommons.org/licenses/by-nc-nd/4.0/) electrode position on the scalp. This is useful to operate the gadgets with brain signals rather than performing actual activity so imagine about moving hand is actually equivalent to moving hand for an BCI application. In literature as per broadmann atlas brain has various segments responsible for specified task. In case of physically challenged case, person can't operate their hands but still can think about movement. In this study author have studied the different patterns of connectivity between the actual ,imaginary motor movement and no motor movement with eyes open and eyes closed, it would help to design brain computer interface to help to survive the physically challenged people. In this study authors has identified the most activated portion of the brain in the form of lobes frontal, temporal, parietal and occipital. Electroencephalography is a non-invasive technique to record brain signals; various signal processing techniques can give insight into the mental state, emotional condition of the person and motion intents. In literature, experiments for recognition or detection of imaginary motion are available with different accuracy and relevance. This approach is beneficial to help the paralysed patients to use the computer application efficiently. EEG Motor Movement/Imagery Dataset was used in [1] available on PhysioNet [2]. 106 volunteers were instructed to perform several real or imaginary movement tasks likes' fists open and close, feet movement, etc. while EEG signals were recorded in 64 channel BCI2000 systems. [1] Eighteen intact and four amputated participants volunteered to perform and/or imagine to perform eleven motor imagery tasks with a single hand in [3] like finger and wrist movements, grasping tasks, etc. Eleven subjects participated for three hand and wrist movements MI experiment - hand opening/ closing, wrist flexion/ extension and forearm pronation/ supination in [4] while EEG data was acquired using G.Nautilus headset with 16 electrodes positioned as per 10/20 system [5]. A dataset of 64 EEG recordings taken in [7] from 25 healthy subjects while performing real and imaginary motor movements of hands and feet. A study comparing Brain computer interface approaches, P300 and Motor Imagery, was done to identify the most efficient BCI based typing application. [9] The EEG signals were recorded using 14 channels Emotiv EEG headset. Three actions were considered for navigating through the virtual keyboard- moving across horizontal axis, vertical axis and selecting the button. The dataset IV a and IV b of BCI competition III was used for Motor Imagery classification in [13] and the results of the algorithms were compared for high dimensional all channel data and just 18 electrode channels in sensory motor cortex area data. Efficient channel selections algorithms help decide which channels to consider for a particular EEG application, since EEG data is recorded from several locations across the brain.

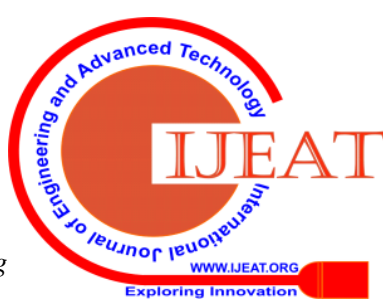


[10] Advantage of channel selection is that it reduces computational complexity and over fitting, removes noise while improving the classification accuracy. Filter, wrapper and hybrid methods for channel selection are discussed in [10]. In filter method channels are ranked with informationbased measures like correlation coefficient, mutual information, etc. In wrapper method, a classifier is used to evaluate the channel subsets. Hybrid method is a combination of the two, a rather ensemble approach. For processing the signals are transformed into time-frequency domain, split into the standard frequency bands of $2-4 \mathrm{~Hz}$ (delta), 4-7 Hz (theta), 8-15 Hz (alpha), 15-29 Hz (beta) and $30-59 \mathrm{~Hz}$ (gamma). Then Hilbert transform is used on the resulting bands to find the overall activity in a band. [1] Features like mean, variance, min, max and sum of squared samples of signal envelope were extracted for [1] for each sub band in each of the sensor or electrode position. Signal envelope differences were calculated and summed up for all the samples, to be considered as another feature. [1]. A sliding window approach is used in [3] to decompose each EEG signal into overlapping segments, convert to timefrequency domain and extract five categories of time frequency features- log-amplitude, amplitude, statistical, spectral, and spectral-entropy based category. Common spatial pattern algorithm was used for feature extraction in [4] from the whole band and then from the five filtered bands. Discrete Wavelet Transform (DWT) is used for features extraction from EEG signals in [6] and input feature vectors like mean, standard deviation, and peak power gave better classification results. Features extraction based on spectral density was explored in [7], after converting the signals into frequency domain and applying Fast Fourier Transform. A quaternion-based signal analysis technique is used in [8] to extract features like average, variance, homogeneity and contrast of EEG signals. Linear Discriminant Analysis along with Common Spatial Pattern is used for feature extraction in [11]. The extracted features are further passed into Sequential Backward Floating Selection Technique to keep only the most optimal features. Second Order Blind Identification, Energy Entropy, and Phase Synchronization measure were some of the features explored in [12] with Fisher class separability criterion to decide on the features. Cross correlation technique was used in [13] for extraction of features like mean, median, mode, standard deviation, maximum and minimum.

For data classification Rough Sets theory was used, that approximates a set by the upper and lower approximation values present. It is done by first including elements that may be present in the set, and then elements that are surely present in the set. [1] A hierarchical classification model of four layers is used in [3] that classify each of the overlapping EEG segments into one of the eleven motor imagery tasks considered. First layer classifies rest or movement segments, second layer classifies between functional and basic movements, third layers further classifies several types of wrist and finger related grasps and movements and finally the fourth layer classifies the eleven motor imagery tasks. Linear Discriminant Analysis (LDA) and Support Vector Machine (SVM) were used for classification on whole band features and filtered band features extracted in [4] and a comparison of accuracy for each combination of features and classifiers was done. Clustering algorithms like k-means, k-med, and hierarchical clustering were used for classification in [7]. While k-means was observed to classify actual motor tasks well, hierarchical clustering worked well for imaginary motor tasks. Boosting techniques on decision trees were used in [8] for classification with and without a sampling window. SVM, KNN and Naïve Bayesian Parzen window are the classifiers used in [11] used for classification of right-hand motor imagery, left hand motor imagery and rest state. Multilayer back propagation neural networks is used in [12] for classification. After cross correlation in [13] LS-SVM classifier with RBF kernel, Logistic Regression and kernel Logistic regression were used for MI classification.

Classification results of rough sets method indicated that universal parameters couldn't be decided upon, and each subject had to be considered differently for parameter selection and classification. [1] For subject dependent training procedures, accuracy obtained in [3] is $88.8 \%$ for intact participants and $90.2 \%$ for amputated participants, and for subject independent training the accuracy was $80.8 \%$ and $87.8 \%$ respectively. Detecting actual motor activity of both hands with $80 \%$ accuracy and imaginary motor activity with just 34\% accuracy in [7]. iQSA technique in [8] gives a $82.3 \%$ accuracy for 0.5 seconds samples of EEG signal recordings, and $73.16 \%$ for 3 seconds samples. The proposed model in [11] gives an accuracy of $60.61 \%$ for Emotiv Epoc headset dataset and $86.50 \%$ for wet gel electrodes. The average classification accuracy of sensor signals in [12] is $72.6 \%$, that of SOBI is $90.6 \%$, energy entropy is $84.4 \%$, and phase synchronization measure is $86.2 \%$. The average accuracy rate for motor area channels in [13] for CC-LS-SVM is $97.12 \%$, CC-LR is $88.18 \%$, CCKLR is $95.35 \%$. For all channels, CC-LS-SVM gives 97.96\% accuracy, CC-LR gives $93.59 \%$ and CC-KLR gives $96.68 \%$.In this study authors have proposed the approach to identify the connectivity among the various electrodes position placed on the scalp. Rest of the paper is organized as section 2 Methodology, section 3 Results and Discussion are present in section 4

\section{METHODOLOGY}

\section{A. Dataset:}

EEG recordings used in this study is taken from [1, 2] and data is captured while subjects were performing actual and imaginary motor movement. For recording device used in this study is BCI2000. Activities performed are two one minute baseline runs with eyes open and eyes closed and three two minute runs of four task 1.Actual left or right fist movement 2.Imaginary left and right fits movement 3.Actual left or right two four minutes runs of Data used in this study has captured from EEG motor movement/imagery.

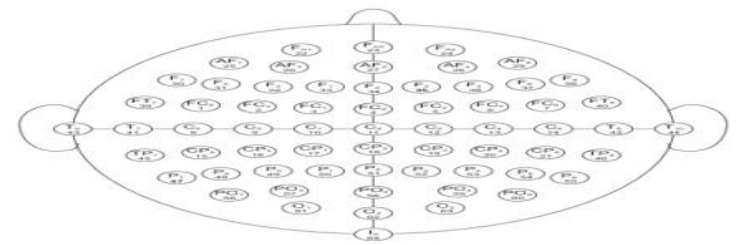

Figure 1: Electrodes Position while capturing brain signals Electrodes not used while recording are Nz, F9, F10, FT9, FT10, A1, A2, TP9, TP10, P9, and P10.The position of the electrodes are as shown in figure 1. 
B. Selection of electrode position, Pre-processing and feature extraction:

As per broad man atlas, four regions of brain frontal,temporal,parietal and occipital is responsible for various functions like execution functions, motor functions, somatosensosory function, attention, visual functions, memory, emotional regulation, sound. In this study authors have to investigate the activated regions associated with eyes open, eyes close, actual motor movement and imaginary motor movement. As per the broadman regions of brain responsible for targeted activity is majorly frontal and occipital. Primary motor movement can be captured by electrode positioning on frontal and parietal lobe, Secondary motor movement can be captured by frontal lobe there is no involvement of parietal lobe in this context. Imaginary motor movement can be captured by placing the electrode on frontal lobe. Eyes blink can be captured easily from frontal lobe. With this knowledge author have selected the electrode position as per 10-20 standards which have a good coverage of frontal, temporal, parietal and occipital region. Electrodes selected are

Frontal: AF3, AF4, F7, F8, F3, F4, FC5, FC6;Temporal: T7 and T8;Parietal: P7, P8 and Occipital: O1 and O2.Original recording has filtered by using the Butterworth high pass filter to remove the frequency above $60 \mathrm{~Hz}$ and connectivity among the various electrode position has been identified .Features has been extracted from the filtered data. Recording of baseline eyes open and eyes close each have samples captured 9760 in 1 min run which results into sampling frequency of $9760 / 60=162.66$ samples/sec. It is segmented into window size of $3 \mathrm{sec}$ each results into 500 data samples and total 19 segments .Features have been extracted from 19 individual segments which result into feature file of $19 * 4$ for each subject and individual channel thus total dimension of feature file for eyes open results into $(19 * 10 * 4) *$ (individual channel).Recording of actual motor movement and imaginary motor movement each have samples captured in 2 min run which results into sampling frequency of $19680 / 120=164$ samples/sec.It is segmented into window size of 750 samples of $4.4 \mathrm{sec}$ and total 26 segments. Features have been extracted from 26 individual segments which result into feature file of $26 * 4$ for each subject and individual channel thus total dimension of feature file for actual and imaginary motor movement results into $(26 * 10 * 4) *$ (individual channel).

\section{Design of Classifier:}

The entire approach used in this study from the selection of appropriate electrode position ,identification of functional connectivity, feature extraction ,statistical significance of the extracted features and building of classifier is as shown in figure 2.

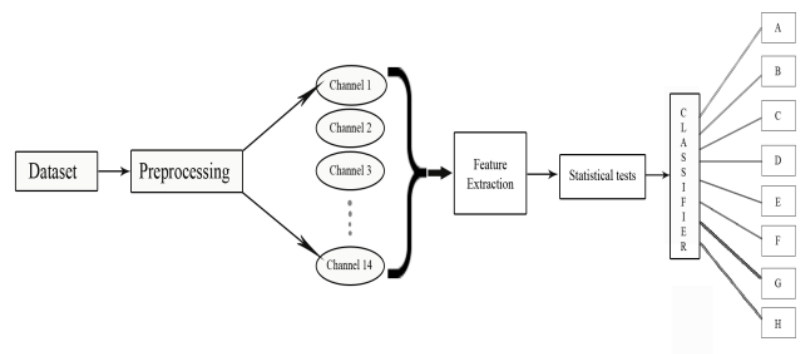

Classifier used in this study is of binary nature results are computed with linear kernel and maximum iteration limit $=100$ and numerical tolerance $=0.0010$.

\section{RESULTS}

\section{A. Connectivity:}

In this study author have identified the network connectivity among the various electrodes placed on the scalp and identified for the study.

In case of eyes open baseline activity results are as shown in table 1: majorly involve portion is frontal region and in only one case temporal and parietal has activated in the strongest way. In case of eyes close baseline activity again no involvement has been observed for the electrodes places on occipital region as shown in table 2.In case of actual motor movement frontal, temporal and parietal has shown the connectivity as shown in table 3 .In table 4 ,the connectivity among the electrodes for imaginary motor movement is observed for the occipital, temporal and parietal whereas very less movement has been observed for frontal region as shown in table 4. In Figure 3 visual connectivity has been shown among the electrodes.

Table 1: Functional connectivity for eyes open baseline activity

\begin{tabular}{|c|c|c|}
\hline $\begin{array}{c}\text { su } \\
b\end{array}$ & Activated(Eyes Open) & Strongest \\
\hline 1 & $\begin{array}{l}\text { AF-3 ,AF- } \\
\text { 4,F7,F8,F3,F4,FC5,FC6,T7,T8,P7,P8,O } \\
2\end{array}$ & $\begin{array}{l}\text { F4- } \\
\text { F8(22.73 } \\
\text { 3) }\end{array}$ \\
\hline 2 & $\begin{array}{l}\text { AF3,AF4,F4,F8,FC5,T7,T8,P7,P8,O1,O } \\
2\end{array}$ & $\begin{array}{l}\text { F3- } \\
\text { P7(11.66 } \\
\text { 7) } \\
\end{array}$ \\
\hline 3 & $\begin{array}{l}\text { AF- } \\
\text { 3,F7,F8,F3,F4,FC5,FC6,T7,T8,P7,P8,O } \\
\text { 2,O1 }\end{array}$ & $\begin{array}{l}\text { F3- } \\
\text { F8;AF3- } \\
\text { O1(12) }\end{array}$ \\
\hline 4 & $\begin{array}{l}\text { AF-3,AF- } \\
\text { 4,F8,F3,F4,FC5,FC6,T7,T8,P7,P8,O2,O } \\
1\end{array}$ & $\begin{array}{l}\text { FC5- } \\
\text { F3(16.83 } \\
\text { 3) }\end{array}$ \\
\hline 5 & $\begin{array}{l}\text { AF- } \\
\text { 4,F7,F8,F3,F4,FC5,FC6,T7,T8,P7,P8,O } \\
\text { 2,O1 }\end{array}$ & $\begin{array}{l}\text { T8- } \\
\text { P8(15.43) }\end{array}$ \\
\hline
\end{tabular}

The Mann whiteney u statistical test at $\mathrm{p}<0.05$ has been carried out on the extracted features kurtosis, skew mean and standard deviation to classify the signals generated by motor and non-motor movement along with actual and imaginary motor movement for various 14 electrode position spread over the scalp of brain. The classification has been carried out as per 8 subsets A, B, C, D, E, F, G, and $\mathrm{H}$ as shown in figure 2. A signifies Eyes open vs Eyes Closed signifies Eyes open vs Actual signifies Eyes Open vs Imaginary, D signifies Eyes closed vs Actual signifies Eyes close vs Imaginary signifies Baseline vs Actual, G signifies Baseline vs Imaginary signifies Actual vs Imaginary. In case A out of the extracted feature mean has not passed the statistical test at the electrode position F7, $\mathrm{FC}$, $\mathrm{T} 7, \mathrm{P} 7, \mathrm{O} 1, \mathrm{O} 2, \mathrm{P} 8$ and $\mathrm{T} 8$. In case $\mathrm{B}$ and $\mathrm{C}$ as per the result of statistical test all the extracted features stand statistically significant for all channel position except for the channel position 
FC6,F8 and AF4,where the feature mean has not passed the statistical significant test.In case D except at the electrode position F8 and AF4 extracted features at all remaining electrode position has passed the statistical test.

In case of E except the feature mean extracted at electrode T7 and F4 all extracted features are statistically significant for rest other electrode position. In case of $F$ the extracted features remain statistically significant for all the electrode position except F8,P8 and T8.In case of G all the extracted features remains statistically significant at all electrode position except $\mathrm{T} 8$ whereas in case of $\mathrm{H}$ the feature mean has not passed the statistical significant test at electrode position P8,T8,FC6,F4,F8,FC6,F4 and AF4.The details of statistical test is as shown in table 5 .

Table 2: Functional connectivity for eyes close baseline activity

\begin{tabular}{|c|c|c|}
\hline sub & Activated(Eyes Close) & Strongest \\
\hline 1 & AF-4,F8,F4,FC6,T7,T8,P7,P8,O1,O2 & F4-F8(9.00) \\
\hline 2 & $\begin{array}{l}\text { AF-3,AF- } \\
\text { 4,F7,F8,F3,F4,FC5,FC6,T7,T8,P7,P8,O2,O1 }\end{array}$ & F4-F8(6) \\
\hline 3 & $\begin{array}{l}\text { AF-3,AF- } \\
\text { 4,F7,F8,F3,F4,FC5,FC6,T7,T8,P7,P8,O2,O1 }\end{array}$ & $\begin{array}{l}\text { FC5- } \\
\text { FC6(29.867) }\end{array}$ \\
\hline 4 & $\begin{array}{l}\text { AF-3,AF- } \\
\text { 4,F7,F8,F3,FC5,FC6,T7,T8,P7,P8,O2,O1 }\end{array}$ & $\begin{array}{l}\text { FC5- } \\
\text { F3;AF4- } \\
\text { F8(5) }\end{array}$ \\
\hline 5 & $\begin{array}{l}\text { AF-3,AF- } \\
\text { 4,F7,F8,F3,F4,FC5,FC6,T7,T8,P7,P8,O2,O1 }\end{array}$ & FC6-O2(40) \\
\hline
\end{tabular}

Table 3: Functional connectivity for actual motor movement

\begin{tabular}{|c|c|c|}
\hline $\begin{array}{c}\mathrm{su} \\
\mathrm{b}\end{array}$ & Activated(Actual) & Strongest \\
\hline 1 & F7,AF3,AF4,F3,F4,FC5,FC6,T8,O1,P8,O2 & $\begin{array}{l}\text { F3- } \\
\text { AF4(4.5) }\end{array}$ \\
\hline 2 & $\begin{array}{l}\text { AF- } \\
\text { 4,F7,F8,F3,F4,FC5,FC6,T7,T8,P7,P8,O2,O1 }\end{array}$ & $\begin{array}{l}\text { T7- } \\
\text { FC5(16) }\end{array}$ \\
\hline 3 & $\begin{array}{l}\text { AF- } \\
\text { 3,F7,F8,F3,F4,FC5,FC6,T7,T8,P7,P8,O2,O1 }\end{array}$ & $\begin{array}{l}\text { FC5- } \\
\text { FC6(7.25) }\end{array}$ \\
\hline 4 & $\begin{array}{l}\text { AF- } \\
\text { 4,F7,F8,F3,F4,FC5,FC6,T7,T8,P7,P8,O2,O1 }\end{array}$ & $\begin{array}{l}\text { AF4- } \\
\text { F8(8) }\end{array}$ \\
\hline 5 & $\begin{array}{l}\text { AF- } \\
\text { 4,AF3,F7,F8,F3,F4,FC5,FC6,T7,T8,P7,P8,O2, } \\
\text { O1 }\end{array}$ & $\begin{array}{l}\text { P7- } \\
\text { AF3(15.8 } \\
785)\end{array}$ \\
\hline
\end{tabular}

Table 4: Functional connectivity for imaginary motor movement

\begin{tabular}{|c|c|c|}
\hline Sub & Activated(Imaginary) & Strongest \\
\hline & AF3,AF4,F7,F3,F8,FC5,FC6, & T8- \\
& T7,T8,P7,P8,O1,O2, & P8(18.1833) \\
\hline & AF- & \\
2 & $4, F 7, F 8, F 3, F 4, F C 5, F C 6, T 7, T 8, P 7, P 8, O 2, O 1$ & AF4-O2(36) \\
\hline & AF-3,AF- & O2- \\
3 & 4,F7,F8,F3,FC5,FC6,T7,T8,P7,P8,O2,O1 & P8(16.933) \\
\hline
\end{tabular}

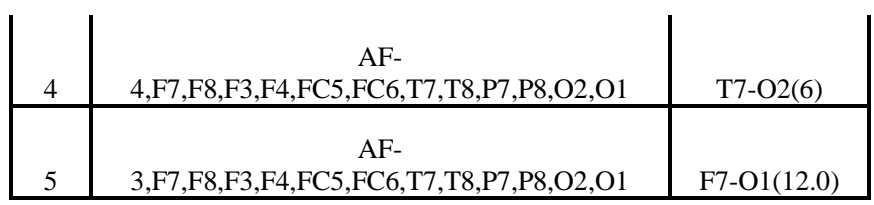

Table 5: Mann Whitney Statistical Test at significance level $\mathbf{p}<\mathbf{0 . 0 5}$

\begin{tabular}{|c|c|c|c|c|c|}
\hline $\begin{array}{l}\text { Subs } \\
\text { ets }\end{array}$ & Channel Position & $\begin{array}{l}\text { Ske } \\
\text { w }\end{array}$ & $\begin{array}{l}\text { Kurt } \\
\text { osis }\end{array}$ & $\begin{array}{l}\text { Stand } \\
\text { ard } \\
\text { Deviat } \\
\text { ion }\end{array}$ & $\begin{array}{l}\text { Me } \\
\text { an }\end{array}$ \\
\hline \multirow[b]{2}{*}{$\mathrm{A}$} & AF3,F3,FC6,F4,F8,AF4 & \multirow[b]{2}{*}{$\checkmark$} & \multirow[b]{2}{*}{$\checkmark$} & \multirow[b]{2}{*}{$\checkmark$} & $\checkmark$ \\
\hline & $\mathrm{F} 7, \mathrm{FC} 5, \mathrm{~T} 7, \mathrm{P} 7, \mathrm{O} 1, \mathrm{O} 2, \mathrm{P} 8, \mathrm{~T} 8$ & & & & $x$ \\
\hline \multirow[b]{2}{*}{$\mathrm{B}$} & $\begin{array}{l}\text { AF3,F7,F3,FC5,T7,P7,O1,O2,P } \\
8, T 8, F 4\end{array}$ & \multirow[b]{2}{*}{$\checkmark$} & \multirow[b]{2}{*}{$\checkmark$} & \multirow[b]{2}{*}{$\checkmark$} & $\checkmark$ \\
\hline & FC6,F8,AF4 & & & & $x$ \\
\hline \multirow[b]{2}{*}{$\mathrm{C}$} & $\begin{array}{l}\text { AF3,F7,F3,FC5,T7,P7,O1,O2,P } \\
\text { 8,T8,F4 }\end{array}$ & \multirow[b]{2}{*}{$\checkmark$} & \multirow[b]{2}{*}{$\checkmark$} & \multirow[b]{2}{*}{$\checkmark$} & $\checkmark$ \\
\hline & FC6,F8,AF4 & & & & $x$ \\
\hline \multirow[b]{2}{*}{$\mathrm{D}$} & $\begin{array}{l}\text { AF3,F7,F3,FC5,T7,P7,O1,O2,P } \\
\text { 8,T8,FC6,F4 }\end{array}$ & \multirow[b]{2}{*}{$\checkmark$} & \multirow[b]{2}{*}{$\checkmark$} & \multirow[b]{2}{*}{$\checkmark$} & $\checkmark$ \\
\hline & F8,AF4 & & & & $x$ \\
\hline \multirow[b]{2}{*}{$\mathrm{E}$} & $\begin{array}{l}\text { AF3,F7,F3,FC5,P7,O1,O2,P8,T } \\
\text { 8,FC6,F4,F8 }\end{array}$ & \multirow[b]{2}{*}{$\checkmark$} & \multirow[b]{2}{*}{$\checkmark$} & \multirow[b]{2}{*}{$\checkmark$} & $\checkmark$ \\
\hline & T7,AF4 & & & & $x$ \\
\hline \multirow[b]{2}{*}{$\mathrm{F}$} & $\begin{array}{l}\text { AF3,F7,F3,FC5,T7,P7,O1,O2,P } \\
\text { 8,T8,F4 }\end{array}$ & \multirow[b]{2}{*}{$\checkmark$} & \multirow[b]{2}{*}{$\checkmark$} & \multirow[b]{2}{*}{$\checkmark$} & $\checkmark$ \\
\hline & FC6,F8,AF4 & & & & $x$ \\
\hline \multirow[b]{2}{*}{ G } & $\begin{array}{l}\text { AF3,F7,F3,FC5,T7,P7,O1,O2,P } \\
\text { 8,T8,FC6,F4,F8 }\end{array}$ & \multirow[b]{2}{*}{$\checkmark$} & \multirow[b]{2}{*}{$\checkmark$} & \multirow[b]{2}{*}{$\checkmark$} & $\checkmark$ \\
\hline & AF4 & & & & $x$ \\
\hline \multirow[b]{2}{*}{$\mathrm{H}$} & P7,O1,O2,FC6,F8,AF4 & \multirow[b]{2}{*}{$\checkmark$} & \multirow[b]{2}{*}{$\checkmark$} & \multirow[b]{2}{*}{$\checkmark$} & $\checkmark$ \\
\hline & AF3,F7,F3,FC5,T7,P8,T8,F4 & & & & $\times$ \\
\hline
\end{tabular}


Figure 3: Functional Connectivity among the electrodes

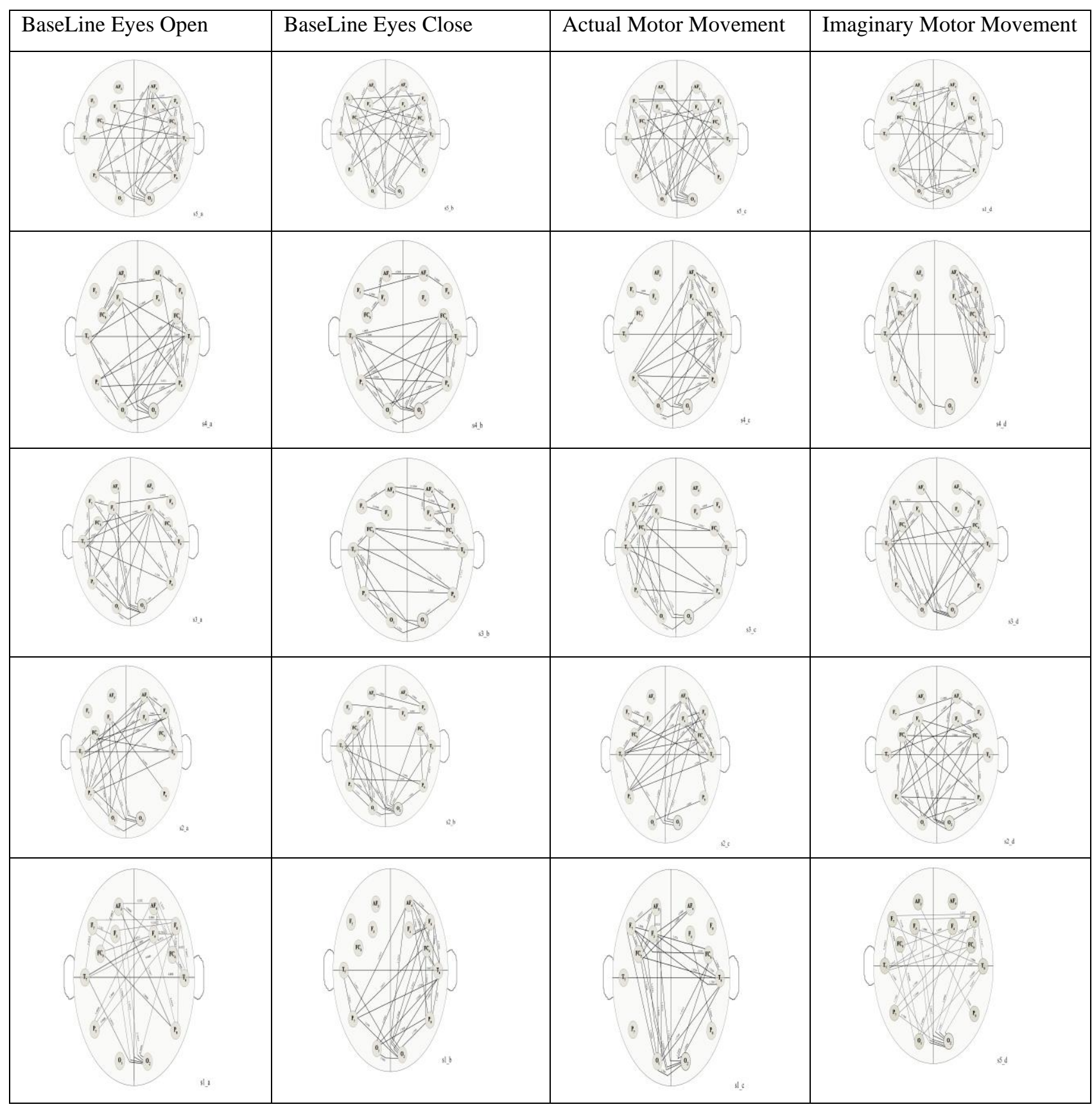

B. Statistical performance of the classifier:

The classifier SVM has been fed with different subsets Actual (B),Eyes Closed vs Actual(C),Eyes Open vs Eyes closed(D),Eyes Open vs Actual( E ),Eyes Open vs Imaginary(F),Baseline vs Actual(G) and Baseline vs Imaginary $(\mathrm{H})$ at 14 electrode positions varied at frontal,temporal,parietal and occipital region. Results retried are sensitivity, specificity and accuracy as shown in table 6 . 
Table 6: Performance of the classifier

\begin{tabular}{|c|c|c|c|c|c|c|c|c|c|c|c|c|c|c|c|c|}
\hline Subsets & & 3 & F7 & F3 & & FC5 & T7 & P7 & 01 & O2 & P8 & T8 & FC6 & F4 & F8 & AF4 \\
\hline \multirow{3}{*}{$\begin{array}{l}\text { Actual } \\
\text { Vs. } \\
\text { Imaginary } \\
\text { (A) }\end{array}$} & $\begin{array}{l}\text { Se } \\
\mathrm{n}\end{array}$ & $\begin{array}{l}11.8 \\
8\end{array}$ & $\begin{array}{l}17.6 \\
2\end{array}$ & & & 9.96 & & & $y$ & $\begin{array}{l}12 . \\
26\end{array}$ & 3.83 & 6.51 & 2.68 & .28 & 4.60 & .36 \\
\hline & $\begin{array}{l}\text { Sp } \\
\text { ec }\end{array}$ & $\begin{array}{l}88.4 \\
6\end{array}$ & $\begin{array}{l}84.6 \\
2\end{array}$ & & & 91.5 & $\begin{array}{l}82.6 \\
9\end{array}$ & $\begin{array}{l}92 \\
3\end{array}$ & $\begin{array}{l}92.2 \\
8\end{array}$ & $\begin{array}{l}94 . \\
62\end{array}$ & $\begin{array}{l}94.2 \\
3\end{array}$ & $\begin{array}{l}95.0 \\
0\end{array}$ & \begin{tabular}{|l|}
97.3 \\
0
\end{tabular} & 2.6 & $\begin{array}{l}94.5 \\
9\end{array}$ & 2.6 \\
\hline & $\begin{array}{l}\text { Ac } \\
\text { C }\end{array}$ & $\begin{array}{l}50.1 \\
0\end{array}$ & $\begin{array}{l}51.0 \\
6\end{array}$ & & & 50.6 & $\begin{array}{l}50.2 \\
9\end{array}$ & $\begin{array}{l}54 \\
3\end{array}$ & $\begin{array}{l}52.8 \\
8\end{array}$ & $\begin{array}{l}53 . \\
36\end{array}$ & $\begin{array}{l}48.9 \\
4\end{array}$ & $\begin{array}{l}50.6 \\
7\end{array}$ & \begin{tabular}{|l|}
49.8 \\
1
\end{tabular} & \begin{tabular}{|l|}
49.8 \\
1
\end{tabular} & $\begin{array}{l}49.4 \\
2\end{array}$ & $\begin{array}{l}48.9 \\
4\end{array}$ \\
\hline \multirow{3}{*}{$\begin{array}{l}\text { Eyes } \\
\text { Closed } \\
\text { Vs. } \\
\text { Imaginary } \\
\text { (B) }\end{array}$} & $\begin{array}{l}\text { Se } \\
\mathrm{n}\end{array}$ & $\begin{array}{l}100 . \\
00\end{array}$ & $\begin{array}{l}100 . \\
00\end{array}$ & $\mathrm{~N}$ & & 99.4 & 100. & & $\begin{array}{l}56.4 \\
7\end{array}$ & $\begin{array}{l}58 . \\
24\end{array}$ & $\begin{array}{l}45.7 \\
0 \\
\end{array}$ & $\begin{array}{l}68.2 \\
1 \\
\end{array}$ & \begin{tabular}{|l}
100. \\
00
\end{tabular} & $\begin{array}{l}100 . \\
00\end{array}$ & $\begin{array}{l}100 . \\
00\end{array}$ & $\begin{array}{l}100 . \\
00\end{array}$ \\
\hline & $\begin{array}{l}\text { Sp } \\
\text { ec }\end{array}$ & $\begin{array}{l}100 . \\
00\end{array}$ & $\begin{array}{l}100 . \\
00\end{array}$ & $\mathrm{~N}$ & & 99.6 & $\begin{array}{l}100 . \\
00\end{array}$ & & $\begin{array}{l}94.9 \\
8\end{array}$ & $\begin{array}{l}93 . \\
91 \\
\end{array}$ & $\begin{array}{l}82.8 \\
9 \\
\end{array}$ & $\begin{array}{l}89.6 \\
0 \\
\end{array}$ & \begin{tabular}{|l|}
100. \\
00 \\
\end{tabular} & $\begin{array}{l}100 . \\
00\end{array}$ & $\begin{array}{ll}100 . \\
00 \\
\end{array}$ & $\begin{array}{ll}100 . \\
00 \\
\end{array}$ \\
\hline & $\begin{array}{l}\text { Ac } \\
\text { c }\end{array}$ & $\begin{array}{l}100 . \\
00\end{array}$ & $\begin{array}{l}100 . \\
00\end{array}$ & $\mathrm{~N}$ & & 69.5 & $\begin{array}{l}100 . \\
00\end{array}$ & & $\begin{array}{l}80.4 \\
0\end{array}$ & $\begin{array}{l}80 . \\
40\end{array}$ & $\begin{array}{l}70.3 \\
8 \\
\end{array}$ & $\begin{array}{l}82.4 \\
1 \\
\end{array}$ & $\begin{array}{l}100 . \\
00\end{array}$ & $\begin{array}{l}100 . \\
00\end{array}$ & & $\begin{array}{l}100 . \\
00 \\
\end{array}$ \\
\hline \multirow{3}{*}{$\begin{array}{l}\text { Eyes } \\
\text { Closed } \\
\text { Vs. } \\
\text { Actual(C) }\end{array}$} & $\begin{array}{l}\text { Se } \\
\mathrm{n}\end{array}$ & $\begin{array}{l}100 . \\
00\end{array}$ & $\begin{array}{l}100 . \\
00\end{array}$ & $\mathrm{~N}$ & & 100. & $\begin{array}{l}100 . \\
00\end{array}$ & & 33 & $\begin{array}{l}22 . \\
94\end{array}$ & $\begin{array}{l}45.0 \\
3 \\
\end{array}$ & $\begin{array}{l}74.6 \\
7\end{array}$ & \begin{tabular}{|l}
100. \\
00
\end{tabular} & 00. & $\begin{array}{l}100 . \\
00\end{array}$ & $\begin{array}{l}00 . \\
0\end{array}$ \\
\hline & $\begin{array}{l}\text { Sp } \\
\text { ec }\end{array}$ & $\begin{array}{l}100 . \\
00\end{array}$ & $\begin{array}{l}100 . \\
00\end{array}$ & $\mathrm{~N}$ & & $\begin{array}{l}100 . \\
00\end{array}$ & $\begin{array}{l}100 . \\
00\end{array}$ & $\begin{array}{l}81 . \\
1\end{array}$ & $\begin{array}{l}79.5 \\
3\end{array}$ & $\begin{array}{l}85 . \\
36\end{array}$ & $\begin{array}{l}52.5 \\
1\end{array}$ & $\begin{array}{l}88.2 \\
9\end{array}$ & \begin{tabular}{|l|}
100. \\
00
\end{tabular} & $\begin{array}{l}00 . \\
0\end{array}$ & & $\begin{array}{l}00 . \\
0\end{array}$ \\
\hline & $\begin{array}{l}\text { Ac } \\
\text { C }\end{array}$ & 100. & $\begin{array}{l}100 . \\
00\end{array}$ & $\mathrm{~N}$ & & $\begin{array}{l}100 . \\
00\end{array}$ & $\begin{array}{l}100 . \\
00\end{array}$ & & 61.0 & 61 & $\begin{array}{l}50.0 \\
0\end{array}$ & $\begin{array}{l}83.7 \\
4\end{array}$ & \begin{tabular}{|l}
100. \\
00
\end{tabular} & 0. & 100. & 00. \\
\hline \multirow{3}{*}{$\begin{array}{l}\text { Eyes } \\
\text { Open Vs. } \\
\text { Eyes } \\
\text { Closed(D } \\
\text { ) }\end{array}$} & $\begin{array}{l}\text { Se } \\
\mathrm{n}\end{array}$ & NA & $\begin{array}{l}17.8 \\
9 \\
\end{array}$ & $\mathrm{~N}$ & & 51.0 & $\begin{array}{l}48.4 \\
2\end{array}$ & $\begin{array}{l}50 . \\
0\end{array}$ & $\begin{array}{l}40.5 \\
3 \\
\end{array}$ & $\begin{array}{l}48 . \\
95 \\
\end{array}$ & $\begin{array}{l}17.3 \\
7 \\
\end{array}$ & $\begin{array}{l}18.4 \\
2\end{array}$ & 5.79 & $\begin{array}{l}14.7 \\
4 \\
\end{array}$ & 9.47 & 3.1 \\
\hline & $\begin{array}{l}\text { Sp } \\
\text { ec }\end{array}$ & $\mathrm{N}$ & $\begin{array}{l}99.4 \\
7\end{array}$ & $\mathrm{~N}$ & & 58.9 & $\begin{array}{l}96.3 \\
0\end{array}$ & & $\begin{array}{l}94.7 \\
1\end{array}$ & $\begin{array}{l}94 . \\
71\end{array}$ & $\begin{array}{l}91.0 \\
1\end{array}$ & $\begin{array}{l}94.1 \\
8\end{array}$ & \begin{tabular}{|l|}
94.7 \\
1
\end{tabular} & $\begin{array}{l}96.8 \\
3 \\
\end{array}$ & $\begin{array}{l}88.3 \\
6\end{array}$ & $\begin{array}{l}87.3 \\
0 \\
\end{array}$ \\
\hline & $\begin{array}{l}\text { Ac } \\
\text { C }\end{array}$ & NA & $\begin{array}{l}58.6 \\
8\end{array}$ & $\mathrm{~N}$ & & 75.0 & $\begin{array}{l}72.3 \\
0\end{array}$ & $\begin{array}{l}68 \\
7\end{array}$ & $\begin{array}{l}67.5 \\
5\end{array}$ & $\begin{array}{l}71 . \\
77\end{array}$ & $\begin{array}{l}54.0 \\
9\end{array}$ & $\begin{array}{l}56.2 \\
0\end{array}$ & $\begin{array}{l}50.1 \\
3\end{array}$ & $\begin{array}{l}55.6 \\
7\end{array}$ & \begin{tabular}{|l}
48.8 \\
1
\end{tabular} & $\begin{array}{l}50.1 \\
3\end{array}$ \\
\hline \multirow{3}{*}{$\begin{array}{l}\text { Eyes } \\
\text { Open Vs. } \\
\text { Actual(E) }\end{array}$} & $\begin{array}{l}\text { Se } \\
\mathrm{n}\end{array}$ & NA & NA & & & $\begin{array}{l}100 . \\
00\end{array}$ & $\begin{array}{l}100 . \\
00\end{array}$ & & $\begin{array}{l}23 \\
6 \\
\end{array}$ & $\begin{array}{l}32 . \\
63 \\
\end{array}$ & $\begin{array}{l}99.4 \\
7 \\
\end{array}$ & $\begin{array}{l}99.4 \\
7 \\
\end{array}$ & $\begin{array}{l}100 . \\
00\end{array}$ & $\begin{array}{l}00 . \\
0 \\
0\end{array}$ & \begin{tabular}{|l}
99.4 \\
7 \\
\end{tabular} & $\begin{array}{l}00 . \\
00 \\
0\end{array}$ \\
\hline & $\begin{array}{l}\mathrm{Sp} \\
\mathrm{ec}\end{array}$ & NA & NA & & & $\begin{array}{l}100 . \\
00\end{array}$ & $\begin{array}{l}100 . \\
00\end{array}$ & & 96 & $\begin{array}{l}96 . \\
55\end{array}$ & $\begin{array}{l}100 . \\
00\end{array}$ & $\begin{array}{l}100 . \\
00\end{array}$ & $\begin{array}{l}100 . \\
00\end{array}$ & $\begin{array}{l}00 . \\
0\end{array}$ & $\begin{array}{l}100 . \\
00\end{array}$ & $\begin{array}{l}100 . \\
00\end{array}$ \\
\hline & $\begin{array}{l}\text { Ac } \\
\mathrm{C}\end{array}$ & NA & $\mathrm{N}$ & 10 & & $\begin{array}{l}100 . \\
00\end{array}$ & $\begin{array}{l}100 . \\
00\end{array}$ & $\begin{array}{l}61 . \\
6\end{array}$ & $\begin{array}{l}65.8 \\
5\end{array}$ & $\begin{array}{l}69 . \\
62 \\
\end{array}$ & $\begin{array}{l}99.7 \\
8\end{array}$ & $\begin{array}{l}99.7 \\
8\end{array}$ & $\begin{array}{l}100 . \\
00\end{array}$ & $\begin{array}{l}100 . \\
00\end{array}$ & $\begin{array}{l}99.7 \\
8 \\
\end{array}$ & 100. \\
\hline \multirow{3}{*}{$\begin{array}{l}\text { Eyes } \\
\text { Open Vs. } \\
\text { Imaginary } \\
\text { (F) }\end{array}$} & $\begin{array}{l}\text { Se } \\
n\end{array}$ & & NA & & & $\begin{array}{l}98.4 \\
2\end{array}$ & $\begin{array}{l}99.4 \\
7\end{array}$ & & 99 & $\begin{array}{l}97 . \\
89\end{array}$ & $\begin{array}{l}99.4 \\
7\end{array}$ & $\begin{array}{l}96.8 \\
4\end{array}$ & $\begin{array}{l}98.4 \\
2\end{array}$ & $\begin{array}{l}97.3 \\
7\end{array}$ & $\begin{array}{l}98.9 \\
5\end{array}$ & 100. \\
\hline & $\begin{array}{l}\mathrm{Sp} \\
\mathrm{ec}\end{array}$ & NA & $\mathrm{N}$ & $\begin{array}{l}10 \\
00 \\
\end{array}$ & & $\begin{array}{l}100 . \\
00\end{array}$ & $\begin{array}{l}100 . \\
00\end{array}$ & $\begin{array}{l}10 \\
00 \\
\end{array}$ & $\begin{array}{l}100 \\
00\end{array}$ & $\begin{array}{l}99 . \\
62 \\
\end{array}$ & $\begin{array}{l}99.6 \\
2 \\
\end{array}$ & $\begin{array}{l}100 . \\
00\end{array}$ & \begin{tabular}{|l}
100. \\
00
\end{tabular} & $\begin{array}{l}100 . \\
00\end{array}$ & \begin{tabular}{|l|}
100. \\
00 \\
\end{tabular} & $\begin{array}{ll}100 . \\
00 \\
\end{array}$ \\
\hline & $\begin{array}{l}\text { Ac } \\
\text { c }\end{array}$ & $\mathrm{N}$ & $\mathrm{N}$ & & $\begin{array}{l}95 \\
3\end{array}$ & 39.3 & $\begin{array}{l}99.7 \\
8\end{array}$ & $\begin{array}{l}99 . \\
6\end{array}$ & $\begin{array}{l}99 \\
8\end{array}$ & $\begin{array}{l}98 . \\
89 \\
\end{array}$ & $\begin{array}{l}99.5 \\
6\end{array}$ & $\begin{array}{l}98.6 \\
7\end{array}$ & \begin{tabular}{|l|}
99.3 \\
3
\end{tabular} & $\begin{array}{l}98.8 \\
9\end{array}$ & $\begin{array}{l}99.5 \\
6\end{array}$ & $\begin{array}{l}100 . \\
00\end{array}$ \\
\hline \multirow{3}{*}{$\begin{array}{l}\text { Eyes } \\
\text { Open } \\
\text { Eyes } \\
\text { Closed vs. } \\
\text { Actual(G) }\end{array}$} & Sen & $\begin{array}{l}\mathrm{N} \\
\mathrm{A}\end{array}$ & $\begin{array}{l}96.3 \\
2\end{array}$ & $\begin{array}{l}\mathrm{N} \\
\mathrm{A}\end{array}$ & $\begin{array}{l}99.4 \\
7\end{array}$ & 10 & & $\begin{array}{l}16.3 \\
6\end{array}$ & $\begin{array}{l}18.5 \\
8\end{array}$ & $\begin{array}{l}25.8 \\
6\end{array}$ & $\begin{array}{l}27.5 \\
8\end{array}$ & $\begin{array}{l}100 . \\
00\end{array}$ & $\begin{array}{l}100 . \\
00\end{array}$ & $\begin{array}{l}100 . \\
00\end{array}$ & $\begin{array}{l}99.7 \\
4\end{array}$ & $\begin{array}{l}100 . \\
00\end{array}$ \\
\hline & $\begin{array}{l}\text { Spe } \\
\text { c }\end{array}$ & $\begin{array}{l}\mathrm{N} \\
\mathrm{A}\end{array}$ & $\begin{array}{l}100 . \\
00 \\
\end{array}$ & $\begin{array}{l}\mathrm{N} \\
\mathrm{A}\end{array}$ & $\begin{array}{l}100 . \\
00 \\
\end{array}$ & 10 & & $\begin{array}{l}96.5 \\
5 \\
\end{array}$ & $\begin{array}{l}97.2 \\
4 \\
\end{array}$ & $\begin{array}{l}95.7 \\
9 \\
\end{array}$ & $\begin{array}{l}93.6 \\
5 \\
\end{array}$ & $\begin{array}{l}100 . \\
00\end{array}$ & $\begin{array}{l}100 . \\
00\end{array}$ & $\begin{array}{l}100 . \\
00 \\
\end{array}$ & $\begin{array}{l}100 . \\
00\end{array}$ & $\begin{array}{l}100 . \\
00\end{array}$ \\
\hline & $\begin{array}{l}\text { Ac } \\
\mathrm{C}\end{array}$ & $\begin{array}{l}\mathrm{N} \\
\mathrm{A}\end{array}$ & $\begin{array}{l}97.8 \\
2 \\
\end{array}$ & $\begin{array}{l}\mathrm{N} \\
\mathrm{A}\end{array}$ & $\begin{array}{l}99.6 \\
9 \\
\end{array}$ & 10 & & $\begin{array}{l}49.0 \\
6\end{array}$ & $\begin{array}{l}47.5 \\
4\end{array}$ & $\begin{array}{l}54.3 \\
8\end{array}$ & $\begin{array}{l}55.1 \\
7 \\
\end{array}$ & $\begin{array}{l}100 . \\
00\end{array}$ & $\begin{array}{l}\text { 100. } \\
00\end{array}$ & $\begin{array}{l}100 . \\
00\end{array}$ & $\begin{array}{l}99.8 \\
4 \\
\end{array}$ & $\begin{array}{l}100 . \\
00\end{array}$ \\
\hline \multirow{3}{*}{$\begin{array}{l}\text { Eyes } \\
\text { Open } \\
\text { Eyes } \\
\text { Closed vs. } \\
\text { Imaginary } \\
\text { (H) }\end{array}$} & Sen & $\begin{array}{l}\mathrm{N} \\
\mathrm{A}\end{array}$ & $\begin{array}{l}95.5 \\
3 \\
\end{array}$ & $\begin{array}{l}\mathrm{N} \\
\mathrm{A}\end{array}$ & $\begin{array}{l}99.4 \\
7 \\
\end{array}$ & \begin{tabular}{l|l}
10 \\
00 \\
\end{tabular} & & $\begin{array}{l}99.7 \\
4 \\
\end{array}$ & $\begin{array}{l}99.4 \\
7 \\
\end{array}$ & $\begin{array}{l}98.6 \\
8 \\
\end{array}$ & $\begin{array}{l}99.7 \\
4 \\
\end{array}$ & $\begin{array}{l}99.2 \\
1 \\
\end{array}$ & $\begin{array}{l}99.7 \\
4 \\
\end{array}$ & $\begin{array}{l}99.2 \\
1 \\
\end{array}$ & $\begin{array}{l}99.4 \\
7 \\
\end{array}$ & $\begin{array}{l}100 . \\
00\end{array}$ \\
\hline & $\begin{array}{l}\text { Spe } \\
\text { c }\end{array}$ & $\begin{array}{l}\mathrm{N} \\
\mathrm{A} \\
\end{array}$ & $\begin{array}{l}100 . \\
00\end{array}$ & $\begin{array}{l}\mathrm{N} \\
\mathrm{A}\end{array}$ & $\begin{array}{l}100 . \\
00\end{array}$ & \begin{tabular}{|l|l|}
10 \\
\end{tabular} & & $\begin{array}{l}100 . \\
00\end{array}$ & $\begin{array}{l}100 . \\
00\end{array}$ & $\begin{array}{l}100 . \\
00\end{array}$ & $\begin{array}{l}100 . \\
00\end{array}$ & $\begin{array}{l}100 . \\
00\end{array}$ & $\begin{array}{l}100 . \\
00\end{array}$ & $\begin{array}{l}100 . \\
00\end{array}$ & $\begin{array}{l}\text { 100. } \\
00\end{array}$ & $\begin{array}{l}100 . \\
00\end{array}$ \\
\hline & $\begin{array}{l}\text { Ac } \\
\mathrm{C}\end{array}$ & $\begin{array}{l}\mathrm{N} \\
\mathrm{A}\end{array}$ & $\begin{array}{l}97.3 \\
4 \\
\end{array}$ & $\begin{array}{l}\mathrm{N} \\
\mathrm{A}\end{array}$ & $\begin{array}{l}99.6 \\
9 \\
\end{array}$ & $\begin{array}{l}10 \\
00\end{array}$ & & $\begin{array}{l}99.8 \\
4 \\
\end{array}$ & $\begin{array}{l}99.6 \\
9 \\
\end{array}$ & $\begin{array}{l}99.2 \\
2 \\
\end{array}$ & $\begin{array}{l}99.8 \\
4 \\
\end{array}$ & $\begin{array}{l}99.5 \\
3 \\
\end{array}$ & $\begin{array}{l}99.8 \\
4 \\
\end{array}$ & $\begin{array}{l}99.5 \\
3 \\
\end{array}$ & $\begin{array}{l}99.6 \\
9 \\
\end{array}$ & $\begin{array}{l}100 . \\
00\end{array}$ \\
\hline
\end{tabular}

\section{DISCUSSION}

The results fetched in this study are significant as per the prominent regions of the scalp. Authors have fetched the results as per the electrode position on the scalp. The functional connectivity results as shown in figure 3 and table1 to 4 . For the baseline eyes open and eyes close activity frontal regions has shown the prominent activity on the scalp and very less intervention has been observed at occipital region as alpha activity is more prominent in this region. In case of imaginary motor movement of left and right fist strongest activation has been observed at almost all the regions of the brain whereas in actual motor movement of left and right fist no involment has been observed of occipital region. 
As shown in table 6 , classification between the actual and imaginary motor movement is very less and which is even expected that there should be very less

difference in the brain activity of actual and imaginary motor movement that's why accuracy lies in the range of $50 \%$ at all the electrode position, which clearly indicates that to provide EEG signal to the brain computer interface by imaginary motor movement stands similar as actual motor movement. In case of baseline eyes closed and imaginary motor movement significant difference has been observed at AF3,F7,T7,P7,FC6,F4,F8 and AF4 whereas no results has been retrieved for the electrode position F3,so frontal region is more prominent for the classification accuracy of no motor movement and imaginary motor movement. In case of baseline eyes open and actual motor movement significant difference has been observed for the electrode position AF3, F7, FC5, T7, FC6, F4, F8 and AF4 and no results has been fetched for electrode position F3.Results I table 6 clearly indicates that for the differentiation between no movement and motor movement (actual /imaginary) frontal region is more prominent and signals generated by eeg can be used to operate an interface for the physical disable person.

\section{REFERENCES}

1. Szczuko, P. (2017). Real and imaginary motion classification based on rough set analysis of EEG signals for multimedia applications. Multimedia Tools and Applications, 76(24), 25697-25711.

2. Goldberger, A. L., Amaral, L. A., Glass, L., Hausdorff, J. M., Ivanov, P. C., Mark, R. G., ... \& Stanley, H. E. (2000). PhysioBank, PhysioToolkit, and PhysioNet: components of a new research resource for complex physiologic signals. Circulation, 101(23), e215-e220.

3. Alazrai, Rami, Hisham Alwanni, Yara Baslan, Nasim Alnuman, and Mohammad Daoud. "Eeg-based brain-computer interface for decoding motor imagery tasks within the same hand using choi-williams timefrequency distribution." Sensors 17, no. 9 (2017): 1937.

4. Suwannarat, A., Pan-ngum, S., \& Israsena, P. (2018). Comparison of EEG measurement of upper limb movement in motor imagery training system. Biomedical engineering online, 17(1), 103.

5. G.Nautilus: Specs and Features. http://www.gtec.at/Produ cts/Hardw areand-Acces sorie s/g.Nauti lus-Specs -Featu res. Accessed 22 Oct 2019.

6. Pattnaik, S., Dash, M., \& Sabut, S. K. (2016, January). DWT-based feature extraction and classification for motor imaginary EEG signals. In 2016 International Conference on Systems in Medicine and Biology (ICSMB) (pp. 186-201). IEEE.

7. Asanza, V., Pelaez, E., \& Loayza, F. (2017, October). EEG signal clustering for motor and imaginary motor tasks on hands and feet. In 2017 IEEE Second Ecuador Technical Chapters Meeting (ETCM) (pp. 1-5). IEEE.

8. Batres-Mendoza, P., Ibarra-Manzano, M. A., Guerra-Hernandez, E. I., Almanza-Ojeda, D. L., Montoro-Sanjose, C. R., Romero-Troncoso, R. J., \& Rostro-Gonzalez, H. (2017). Improving EEG-based motor imagery classification for real-time applications using the QSA method. Computational intelligence and neuroscience, 2017.

9. Al-Negheimish, H., Al-Andas, L., Al-Mofeez, L., Al-Abdullatif, A., AlKhalifa, N., \& Al-Wabil, A. (2013, July). Brainwave typing: Comparative study of p300 and motor imagery for typing using dryelectrode EEG devices. In International Conference on HumanComputer Interaction (pp. 569-573). Springer, Berlin, Heidelberg.

10.Baig, M. Z., Aslam, N., \& Shum, H. P. (2019). Filtering techniques for channel selection in motor imagery EEG applications: a survey. Artificial intelligence review, 1-26.

11.Khan, J., Bhatti, M. H., Khan, U. G., \& Iqbal, R. (2019). Multiclass EEG motor-imagery classification with sub-band common spatial patterns. EURASIP Journal on Wireless Communications and Networking, 2019(1), 174.

12.Xiao, D. (2011). Comparison of Three Motor Imagery EEG Signal Processing Methods. In Advances in Multimedia, Software Engineering and Computing Vol. 2 (pp. 503-508). Springer, Berlin, Heidelberg.

13.Siuly, S., Li, Y., \& Zhang, Y. (2016). EEG signal analysis and classification. IEEE Transactions on Neural Systems and Rehabilitaiton Engineering, 11, 141-144.

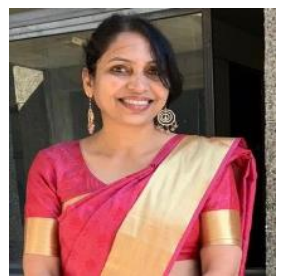

\section{AUTHORS PROFILE}

Dr. Nilima Salankar has done her BE.Mtech and $\mathrm{PhD}$ in Computer Science and Engineering. Her research interest area is human computer Interaction, cognitive science; Signal processing, Machine Intelligence and Academic Research.

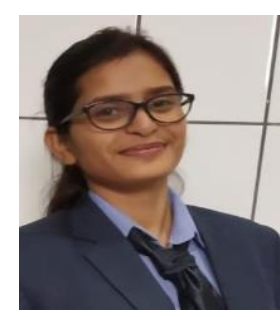

Anjali Mishra is currently pursuing Master of Technology in Computer Science with specialization in Artificial Intelligence from University of Petroleum and Energy Studies, Dehradun. She received her B.Tech in CSE from Maya Institute of Technology and Management, Dehradun in 2017. Her research interests in Machine Learning include Natural Language Processing, EEG signal processing and other healthcare related domains.

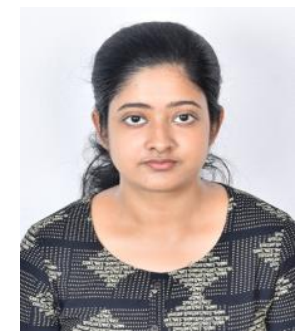

Pratikshya Mishra is a second year M.Tech student with specialization in Artificial Intelligence, School of Computer Science University of Petroleum and Energy Studies, Dehradun. She received her B.Tech in Electronics and Communication Engineering from Siksha O Anusandhan University, Bhubaneswar in 2015. Her research interests in the area of machine learning include EEG signal and time series data analysis. 